\title{
THERMAL STABILITY OF Ni(II) AND Cu(II) MIXED LIGAND COMPLEXES DERIVED FROM BIOLOGICALLY IMPORTANT SCHIFF BASES, AZOLES AND MORPHOLINE
}

Aref A.M. Aly ${ }^{1}$, Ahmed H. Osman ${ }^{1}$, Mohamed Abd El-Mottaleb ${ }^{2}$ and Gamal A.H. Gouda ${ }^{2}$

${ }^{1}$ Department of Chemistry, Faculty of Science, Assiut University, Assiut, Egypt

${ }^{2}$ Department of Chemistry, Faculty of Science, Al-Azhar University, Assiut, Egypt

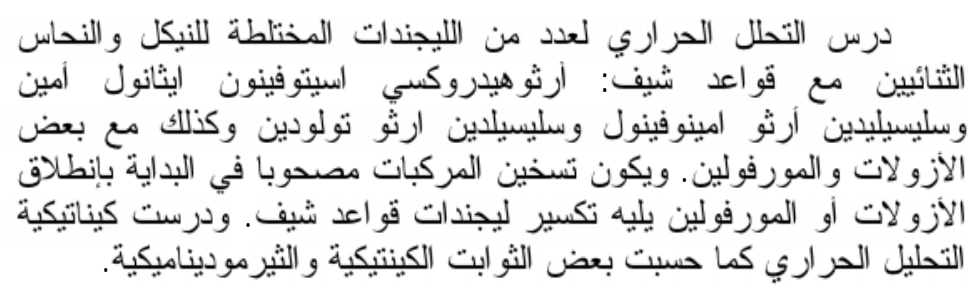

Thermogravimetry (TG) and differential thermogravimetry (DTG) have been applied to the investigation of the thermal behavior of six mixed ligand complexes of $\mathrm{Ni}(\mathrm{II})$ and $\mathrm{Cu}(\mathrm{II})$ comprising the Schiff bases: o-hydroxyacetophenoneethanolimine (OHAE), N-salicylidene-o-iminophenol (SOP) and N-salicylideneo-toluidine (SOT) as well as morpholine (Morph) and certain azoles. The azoles used are: 2-amino-thiazole (2-Atz), benzothiazole (Btz), 2-methylbenzothiazole (2-Mbtz), 3-methyl-2selenoxobenzothiazole (3-Msbtz) and thiabendazole (Tbdz). Heating the compounds first results in a release of the morpholine or the azoles. Kinetics of the decomposition reactions were studied using non-mechanistic equations.

\section{INTRODUCTION}

Schiff bases continue to occupy an important position as ligands in coordination chemistry even after almost a century. Complexes of Schiff bases with metals were found to perform a crucial role in 
biological systems ${ }^{1}$. Their metal complexes are noted for their antifungal and antibacterial activities, where the increase in these activities may be due to the effect of the metal ion on the normal cell process ${ }^{2 \& 3}$. Furthermore, it is well documented that heterocyclic compounds play a significant role in many biological systems, especially $\mathrm{N}$-donor ligand systems being a component of several vitamins and drugs ${ }^{4-6}$.

In view of the biological importance of Schiff bases and heterocyclic compounds and in view of our interest in the coordination chemistry of these ligands $^{7-10}$, the present article describes the thermal decomposition of a number of mixed ligand complexes of $\mathrm{Ni}$ (II) and $\mathrm{Cu}$ (II) with Schiff bases azoles and morpholine in order to enhance more understanding of drug-metal ion interactions.

\section{EXPERIMENTAL}

All solvents and reagents used in this work were of analytical grades. The mixed ligand complexes were prepared according to reported literature procedures ${ }^{10}$. The thermal studies were carried out in nitrogen flow $(20 \mathrm{ml} / \mathrm{min})$ on a Shimadzu analyzer $\mathrm{SOH}$, heating rate being adjusted to $10^{\circ} \mathrm{C} / \mathrm{min}$.

\section{RESULTS AND DISCUSSION}

The structure of the complexes as reproduced from reference 10 are depicted in Fig. 1. The thermal decomposition data of the compounds are collected in Tables 1 and 2. The complexes are thermally relatively stable and thermal decompositions of the compounds are multistage processes. Subsequent detachment of the ligands was observed. The complexes were subjected to a TG analysis from $50-700^{\circ} \mathrm{C}$ in nitrogen atmosphere.

The thermoanalysis curve of $[\mathrm{Cu}(\mathrm{OHAE})(2-\mathrm{Atz})]$ involves five successive steps in the temperature ranges 75-150, 153-243, 250-315, $360-475$ and $650-725^{\circ} \mathrm{C}$. The first and second steps are connected with the expulsion of the 2-aminothiazole molecule (calc. 29.3\%, found $30.0 \%$ ) (eq. 1). The third step of mass loss $28.3 \%$ has an activation energy of $46.9 \mathrm{~kJ} / \mathrm{mol}$. The TG curve displays the fourth and the fifth steps as small steps with mass losses of 5.3 and $5.9 \%$, respectively. However, the fifth step is characterized by an activation energy of $228.7 \% \mathrm{~kJ} / \mathrm{mol}$.

$$
\underset{[\mathrm{Cu}(\mathrm{OHAE})]+2-\mathrm{Atz}}{[\mathrm{Cu}(\mathrm{OHAE})(2-\mathrm{Atz})] \stackrel{75-243^{\circ} \mathrm{C}}{\longrightarrow}}
$$

For $[\mathrm{Cu}(\mathrm{OHAE})(\mathrm{Btz})]$ the $\mathrm{TG}$ thermogram (Fig. 2) reveals four decomposition steps. The first step $\left(40-175^{\circ} \mathrm{C}\right)$ is commensurate with 


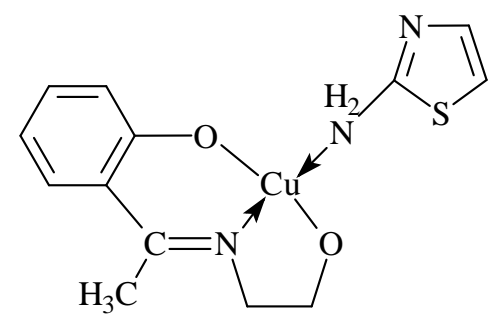

$\mathrm{Cu}((\mathrm{OHAE})(2-\mathrm{Atz})]$<smiles>CC1=[N+]2CCO[C@](n3c(=S)sc4ccccc43)(O1)Oc1ccccc12</smiles>

[Cu(OHAE)(3-Msbtz)]

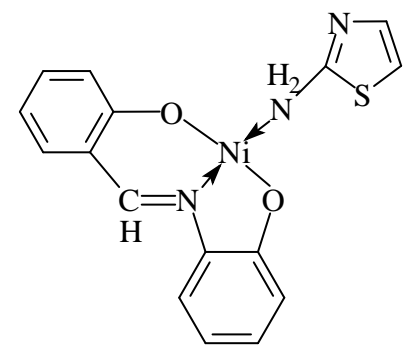

[Ni(SOP)(2-Atz)]

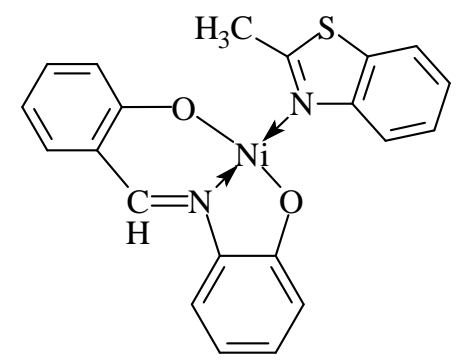

Ni(SOP)(2-Mbtz)]

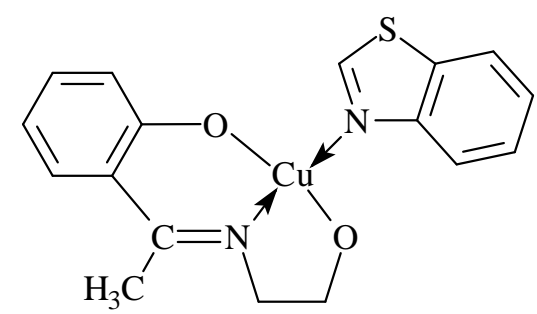

[Cu(OHAE)(Btz)]

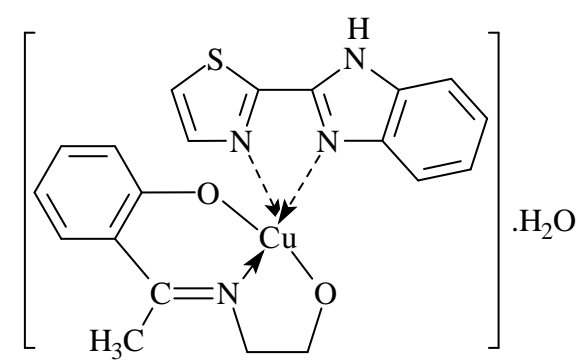

$[\mathrm{Cu}(\mathrm{OHAE})(\mathrm{Tbdz})] \cdot \mathrm{H}_{2} \mathrm{O}$

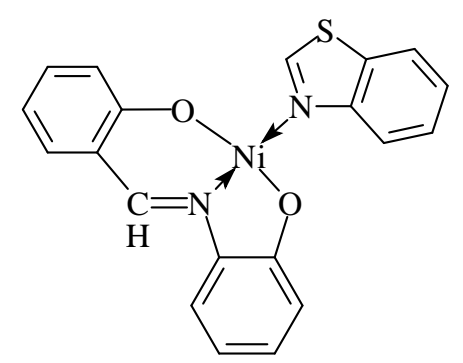

[Ni(SOP)(Btz]

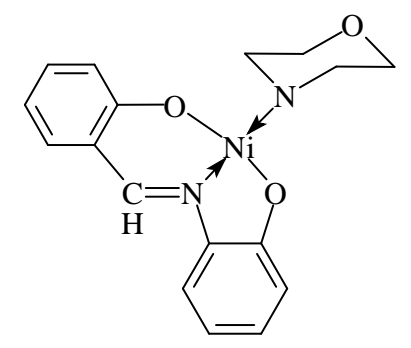

[Ni(SOP)(Morph)] 


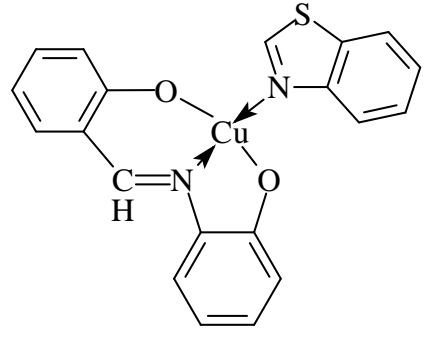

$[\mathrm{Cu}(\mathrm{SOP})(\mathrm{Btz})]$

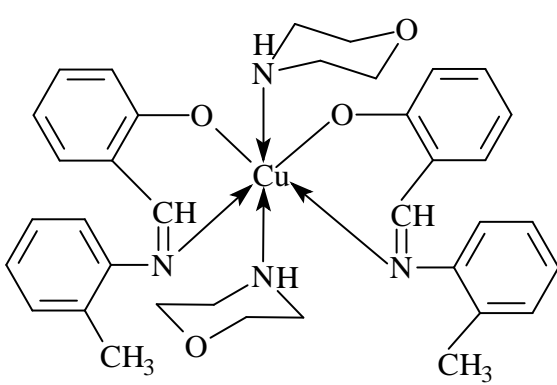

$\left[\mathrm{Cu}(\mathrm{SOT})_{2}(\mathrm{Morph})_{2}\right]$

Fig. 1: The structures of the complexes.

Table 1: Thermal decomposition data of the compounds in nitrogen flow.

\begin{tabular}{||l|c|c|c|c|c|}
\hline \multirow{2}{*}{ Compound } & \multirow{2}{*}{ Step } & \multicolumn{3}{|c|}{ TG/DTG } & Mass loss \\
\cline { 3 - 5 } & & $\mathrm{T}_{\mathrm{i}} /{ }^{\circ} \mathrm{C}$ & $\mathrm{T}_{\mathrm{m}} /{ }^{\circ} \mathrm{C}$ & $\mathrm{T}_{\mathrm{f}} /{ }^{\circ} \mathrm{C}$ & $(\%)$ \\
\hline$[\mathrm{Cu}(\mathrm{OHAE})(2-\mathrm{Atz})]$ & $1^{\text {st }}$ & 75 & 105 & 150 & 14.9 \\
& $2^{\text {nd }}$ & 153 & 190 & 243 & 15.1 \\
& $3^{\text {rd }}$ & 250 & 287 & 315 & 28.3 \\
& $4^{\text {th }}$ & 360 & 415 & 475 & 5.3 \\
& $5^{\text {th }}$ & 650 & 710 & 725 & 5.9 \\
\hline$[\mathrm{Cu}(\mathrm{OHAE})(\mathrm{Btz})]$ & $1^{\text {st }}$ & 40 & 128 & 157 & 36.5 \\
& $2^{\text {nd }}$ & 264 & 285 & 307 & 25.3 \\
& $3^{\text {rd }}$ & 362 & 403 & 444 & 4.5 \\
& $4^{\text {th }}$ & 630 & 700 & 788 & 4.7 \\
\hline$[\mathrm{Cu}(\mathrm{OHAE})(3-\mathrm{Msbtz})]$ & $1^{\text {st }}$ & 60 & 75 & 100 & 5.6 \\
& $2^{\text {nd }}$ & 103 & 140 & 230 & 43.5 \\
& $3^{\text {rd }}$ & 240 & 305 & 375 & 31.7 \\
& $4^{\text {th }}$ & 450 & 475 & 490 & 5.8 \\
& $5^{\text {th }}$ & 600 & 650 & 700 & 4.5 \\
\hline$[\mathrm{Cu}(\mathrm{OHAE})(\mathrm{Tbdz})] \cdot \mathrm{H}_{2}$ & $1^{\text {st }}$ & 50 & 90 & 150 & 4.0 \\
$\mathrm{O}$ & $2^{\text {nd }}$ & 150 & 210 & 275 & 43.8 \\
& $3^{\text {rd }}$ & 278 & 325 & 390 & 20.7 \\
& $4^{\text {th }}$ & 590 & 650 & 715 & 3.5 \\
\hline
\end{tabular}

$\mathrm{T}_{\mathrm{i}}=$ Initial temperature.

$\mathrm{T}_{\mathrm{m}}=$ Maximum temperature.

$\mathrm{T}_{\mathrm{f}}=$ Final temperature. 
Table 2: Thermal decomposition data of the compounds in nitrogen flow (contd.).

\begin{tabular}{|l|c|c|c|c|c||}
\hline \multirow{2}{*}{ Compound } & \multirow{2}{*}{ Step } & \multicolumn{3}{|c|}{ TG/DTG } & Mass loss \\
\cline { 3 - 5 } & & $\mathrm{T}_{\mathrm{i}} /{ }^{\circ} \mathrm{C}$ & $\mathrm{T}_{\mathrm{m}} /{ }^{\circ} \mathrm{C}$ & $\mathrm{T}_{\mathrm{f}} /{ }^{\circ} \mathrm{C}$ & $(\%)$ \\
\hline$[\mathrm{Ni}(\mathrm{SOP})(2-\mathrm{Atz})]$ & $1^{\text {st }}$ & 100 & 126 & 150 & 6.3 \\
& $2^{\text {nd }}$ & 150 & 175 & 300 & 20.7 \\
& $3^{\text {rd }}$ & 350 & 430 & 450 & 20.5 \\
& $4^{\text {th }}$ & 452 & 530 & 600 & 29.5 \\
\hline$[\mathrm{Ni}(\mathrm{SOP})(\mathrm{Btz})]$ & $1^{\text {st }}$ & 100 & 178 & 250 & 33.5 \\
& $2^{\text {nd }}$ & 395 & 428 & 547 & 24.7 \\
& $3^{\text {rd }}$ & 480 & 528 & 540 & 26.3 \\
\hline$[\mathrm{Ni}(\mathrm{SOP})(2-\mathrm{Mbtz})]$ & $1^{\text {st }}$ & 55 & 125 & 280 & 36.0 \\
& $2^{\text {nd }}$ & 355 & 425 & 460 & 19.3 \\
& $3^{\text {rd }}$ & 475 & 525 & 570 & 23.5 \\
\hline$[\mathrm{Ni}(\mathrm{SOP})(\mathrm{Morph})]$ & $1^{\text {st }}$ & 75 & 211 & 320 & 25.0 \\
& $2^{\text {nd }}$ & 325 & 428 & 460 & 26.8 \\
& $3^{\text {rd }}$ & 470 & 531 & 600 & 25.5 \\
\hline$[\mathrm{Cu}(\mathrm{SOP})(\mathrm{Btz})]$ & $1^{\text {st }}$ & 49 & 128 & 290 & 33.0 \\
& $2^{\text {nd }}$ & 300 & 364 & 450 & 57.5 \\
\hline$\left[\mathrm{Cu}(\mathrm{SOT})_{2}(\mathrm{Morph})_{2}\right]$ & $1^{\text {st }}$ & 50 & $48-209$ & 299 & 27.0 \\
& $2^{\text {nd }}$ & 325 & 385 & 453 & 32.5 \\
\hline
\end{tabular}

$\mathrm{T}_{\mathrm{i}}=$ Initial temperature.

$\mathrm{T}_{\mathrm{m}}=$ Maximum temperature.

$\mathrm{T}_{\mathrm{f}}=$ Final temperature.

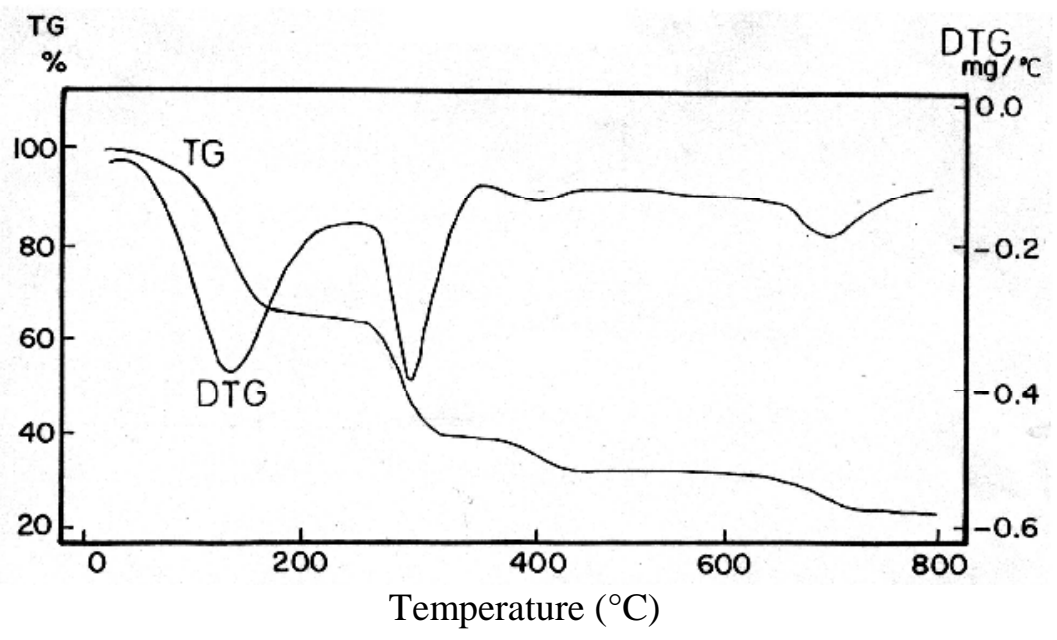

Fig. 2: TG-DTG curves of [Cu(OHAE)(Btz)] 
the expulsion of the benzothiazole molecule (calc. 35.9\%, found $36.5 \%$ ) (eq. 2) with an activation energy of $48.1 \mathrm{~kJ} / \mathrm{mol}$. The second mass loss $(25.3 \%)$ occurs in the temperature range $264-307^{\circ} \mathrm{C}$ with an activation energy of $93.9 \mathrm{~kJ} / \mathrm{mol}$. The third $(4.5 \%)$ and fourth $(4.7 \%)$ steps which represent the smallest steps are shown on the TG trace in the temperature ranges $362-444$ and $630-788^{\circ} \mathrm{C}$, respectively.

$$
\underset{[\mathrm{Cu}(\mathrm{OHAE})]+\mathrm{Btz}}{[\mathrm{Cu}(\mathrm{OHAE})(\mathrm{Btz})] \stackrel{40-157^{\circ} \mathrm{C}}{\longrightarrow}}
$$

The TG profile of [Cu(OHAE)(3-Msbtz)] exhibits five decomposition steps in the temperature ranges $60-100,103-$ $230,240-375,450-490$ and 600$700^{\circ} \mathrm{C}$. The first and second steps correspond to the decomposition of 3-methyl-2-selenoxobenzothiazole (calc. $48.6 \%$, found $49.1 \%$ ) (eq. 3). The calculated activation energy for the second and the third steps are $50.6 \mathrm{~kJ} / \mathrm{mol}$ and $95.5 \mathrm{~kJ} / \mathrm{mol}$, respecitvely. The fourth $(5.8 \%)$ and fifth $(4.5 \%)$ steps are the smallest ones.

$$
\begin{aligned}
& {[\mathrm{Cu}(\mathrm{OHAE})(3-\mathrm{Msbtz})] \stackrel{60-230^{\circ} \mathrm{C}}{\longrightarrow}} \\
& {[\mathrm{Cu}(\mathrm{OHAE})]+3-\mathrm{Msbtz}}
\end{aligned}
$$

$[\mathrm{Cu}(\mathrm{OHAE})(\mathrm{Tbdz})] \cdot \mathrm{H}_{2} \mathrm{O}$ undergoes a stepwise decomposition in four decomposition stages well discernible in the TG and DTG curves in the temperature ranges 50$150,150-275,278-390$ and 690- $715^{\circ} \mathrm{C}$. The mass loss at the first step points to the elimination of a water molecule (calc. $4.0 \%$, found 4.1\%). The DTG curve displays this mass loss at $90^{\circ} \mathrm{C}$ indicating that this water molecule can be considered as lattice water (eq. 4). The second step is commensurate with the release of the thiabendazole molecule (calc. $43.7 \%$, found $43.8 \%$ ) (eq. 5). This step is associated with an activation energy amounts to $50.9 \mathrm{~kJ} / \mathrm{mol}$. The third step $(20.7 \%)$ has an activation energy of $70.5 \% \mathrm{~kJ} / \mathrm{mol}$. The fourth step of $3.5 \%$ mass loss is a small step. The end product corresponds to $\mathrm{CuO}$ (calc. $17.9 \%$, found $19.0 \%$ ).

$\underset{[\mathrm{Cu}(\mathrm{OHAE})(\mathrm{Tbdz})]+\mathrm{H}_{2} \mathrm{O}(4)}{\stackrel{\mathrm{Cu}(\mathrm{OHAE})(\mathrm{Tbdz})] \mathrm{H}_{2} \mathrm{O}}{\stackrel{50-150^{\circ} \mathrm{C}}{\longrightarrow}}}$

$$
\underset{[\mathrm{Cu}(\mathrm{OHAE})]+\mathrm{Tbdz}}{\stackrel{150-275^{\circ} \mathrm{C}}{\longrightarrow}}
$$

The thermal curve of [Ni(SOP)(2-Atz)] indicates a fourstage thermal decomposition in the temperature range 100-150, 150$300,350-450$ and $452-600^{\circ} \mathrm{C}$. A small step $(2.1 \%)$ appears at about $95^{\circ} \mathrm{C}$ (DTG peak) which is ascribed to absorbed water. The first and second steps are suggested to represent decomposition of the 2 aminothiazole molecule (calc. $27.4 \%$, found $27.0 \%$ ) (eq. 6). The third step of $20.5 \%$ mass loss is characterized by an activation energy of $182.5 \mathrm{~kJ} / \mathrm{mol}$. For the fourth step $(29.5 \%)$ the calculated 
activation energy was found to be $150.2 \mathrm{~kJ} / \mathrm{mol}$. Based on the weight loss consideration $\mathrm{NiO}$ was the final residue (calc. $24.5 \%$, found $25.0 \%$ ).

$$
\begin{aligned}
& {[\mathrm{Ni}(\mathrm{SOP})(2-\mathrm{Atz})] \stackrel{100-300^{\circ} \mathrm{C}}{\longrightarrow}} \\
& {[\mathrm{Ni}(\mathrm{SOP})]+2-\mathrm{Atz}}
\end{aligned}
$$

The TG profile of $[\mathrm{Ni}(\mathrm{SOP})(\mathrm{Btz})]$ exhibits three decomposition steps in the temperature ranges 100-250, 395457 and $480-542^{\circ} \mathrm{C}$. The first step accounts for the release of the benzothiazole molecule (calc. $33.3 \%$, found $33.7 \%$ ) (eq. 7) with an activation energy of $43.2 \mathrm{~kJ} / \mathrm{mol}$. The second step represents a mass loss of $24.7 \%$, with an activation energy of $140.0 \mathrm{~kJ} / \mathrm{mol}$. The third step (26.3\%) has an activation energy of $95.6 \mathrm{~kJ} / \mathrm{mol}$. The residual mass is greater than that calculated for $\mathrm{NiO}$ (calc. $19.4 \%$, found $20.0 \%$ ). It is possible that part of the carbon liberated from thermal decomposition of the ligands is included in the residue.

$$
\underset{[\mathrm{Ni}(\mathrm{SOP})]+\mathrm{Btz}}{[\mathrm{Ni}(\mathrm{SOP})(\mathrm{Btz})] \stackrel{100-250^{\circ} \mathrm{C}}{\longrightarrow}}
$$

The thermal curve of [Ni(SOP)(2-Mbtz)] indicates a three-stage thermal decomposition in the temperature ranges 55-280, $355-460$ and $475-525^{\circ} \mathrm{C}$. The first step is composed of two overlapping steps appearing separated in the DTG curve. The first step suggests decomposition of the 2-methylbenzothiazole molecule (calc. $35.6 \%$, found $36.0 \%$ ) (eq. 8). The second step $19.3 \%$ has an activation energy of $140.9 \mathrm{~kJ} / \mathrm{mol}$. The third step possesses a mass loss of $23.5 \%$ and the calculated activation energy amounts to 96.6 $\mathrm{kJ} / \mathrm{mol}$. $\mathrm{NiO}$ is the final product (calc. $18.9 \%$, found $19.5 \%$ ).

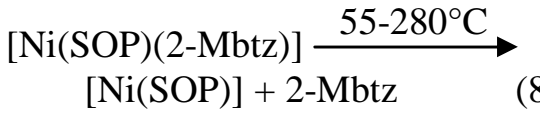

[Ni(SOP)(Morph)] undergoes a decomposition in three stages in the $75-320, \quad 325-460$ and $470-600^{\circ} \mathrm{C}$ temperature ranges. The first step is a slow step and is connected with the evolution of a morpholine molecule (calc. 24.4\%, found $25.0 \%$ ) (eq. 9) with an activation energy of $32.1 \mathrm{~kJ} / \mathrm{mol}$. The second step $(26.8 \%)$ has an activation energy of $113.7 \mathrm{~kJ} / \mathrm{mol}$. The third mass loss $(25.5 \%)$ is associated with an activation energy of 126.7 $\mathrm{kJ} / \mathrm{mol}$.

$$
\begin{aligned}
& {[\mathrm{Ni}(\mathrm{SOP})(\mathrm{Morph})] \stackrel{75-320^{\circ} \mathrm{C}}{\longrightarrow}} \\
& {[\mathrm{Ni}(\mathrm{SOP})]+\mathrm{Morph}}
\end{aligned}
$$

The pyrolysis curve of $[\mathrm{Cu}(\mathrm{SOP})(\mathrm{Btz})]$ yields two steps in the temperature ranges 49-290 and $300-320^{\circ} \mathrm{C}$. The first step accounts for the expulsion of the benzothiazole molecule (calc. 33.0\%, found $32.3 \%$ ) (eq. 10) with an activation energy of $41.0 \mathrm{~kJ} / \mathrm{mol}$. The second step is a major step 
$(57.5 \%)$ and possesses an activation energy of $45.6 \mathrm{~kJ} / \mathrm{mol}$.

$$
\underset{[\mathrm{Cu}(\mathrm{SOP})]+\mathrm{Btz}}{[\mathrm{Cu}(\mathrm{SOP})(\mathrm{Btz})] \stackrel{100-300^{\circ} \mathrm{C}}{\longrightarrow}}
$$

The TG thermogram of $\left[\mathrm{Cu}(\mathrm{SOT})_{2}(\mathrm{Morph})_{2}\right]$ displays two stages in the temperature ranges 50299 and $325-455^{\circ} \mathrm{C}$. The first step seems to be composed of two overlapping steps but well separated on the DTG curve. This step may be associated with the liberation of two morpholine molecules (calc. $26.4 \%$, found $27.0 \%$ ) (eq. 11). The second step $(32.5 \%)$ is a rather fast step with an activation energy of 139.7 $\mathrm{kJ} / \mathrm{mol}$.

$$
\begin{aligned}
& {\left[\mathrm{Cu}(\mathrm{SOT})_{2}(\mathrm{Morph})_{2}\right] \stackrel{50-299^{\circ} \mathrm{C}}{\longrightarrow}} \\
& {\left[\mathrm{Cu}(\mathrm{SOT})_{2}\right]+2 \mathrm{Morph}}
\end{aligned}
$$

\section{Evaluation of the kinetic parameters}

The kinetic parameters were evaluated only for clear-cut and non-overlapping stages. Kinetic studies were not attempted for decomposition stages, which occur within a very narrow temperature range because accuracy of the measurements without a sufficient number of points from the curve could not be obtained to derive meaningful results for kinetic parameters. According to CoatsRedfern $^{11}$ and Horowitz-Metzger ${ }^{12}$ the kinetic parameters $\mathrm{n}, \mathrm{E}$ and $\mathrm{Z}$ can be calculated by means of the following equations:

\section{Coats-Redfern equation}

$$
\begin{gathered}
\ln \left[\frac{1-(1-\alpha)^{1-n}}{(1-n) T^{2}}\right]=M / T+\mathrm{B} \\
\text { for } \mathrm{n} \neq 1
\end{gathered}
$$

$$
\begin{array}{r}
\ln \left[\frac{-\ln (1-\alpha)}{T^{2}}\right]=M / T+\mathrm{B} \\
\text { for } \mathrm{n}=1
\end{array}
$$

where $\alpha$ is the fraction of material reacted, $\mathrm{n}$ is the order of the decomposition reaction and $\mathrm{M}=$ $-\mathrm{E} / \mathrm{R}$ and $\mathrm{B}=\mathrm{ZR} / \phi \mathrm{E}$; where $\mathrm{E}, \mathrm{R}, \mathrm{Z}$ and $\phi$ are the activation energy, gas constant, pre-exponential factor and heating rate, respectively.

\section{Horowitz-Metzger equation}

$$
\begin{aligned}
& \ln \left[\frac{1-(1-\alpha)^{1-n}}{1-n}\right]=\ln \frac{Z R T_{S}^{2}}{\phi E}- \\
& \frac{\mathrm{E}}{\mathrm{RT}_{\mathrm{S}}}+\frac{\mathrm{E} \theta}{\mathrm{RT}_{\mathrm{S}}^{2}} \quad \text { for } \mathrm{n} \neq 1 \\
& \ln [-\ln (1-\alpha)]=\frac{\mathrm{E} \theta}{\mathrm{RT}_{\mathrm{S}}^{2}} \\
& \text { for } \mathrm{n}=1
\end{aligned}
$$

where $\theta=\mathrm{T}-\mathrm{T}_{\mathrm{S}}, \mathrm{T}_{\mathrm{S}}$ is the temperature at the DTG peak.

The correlation coefficient $r$ is computed using the least squares method for equations (12), (13), (14) and (15). Linear curves were drawn for different values of $n$ 
ranging from 0 to 2 . The value of $n$, which gave the best fit, was chosen as the order parameter for the decomposition stage of interest. The kinetic parameters were calculated from the plots of the left hand side of equations (12) and (13) against $1 / \mathrm{T}$ and against $\theta$ for equations (14) and (15).

Changes in entropy $\left(\Delta \mathrm{S}^{*}\right)$, enthalpy $\left(\Delta H^{*}\right)$ and free energy $\left(\Delta \mathrm{G}^{*}\right)$ of activation $^{13}$ were computed using equations (16), (17) and (18).

$$
\begin{aligned}
\Delta S^{*} & =2.303\left(\log \frac{Z h}{k T_{S}}\right) \mathrm{R} \\
\Delta H^{*} & =E-R T_{S} \\
\Delta G^{*} & =\Delta H^{*}-T_{S} \Delta S^{*}
\end{aligned}
$$

where $\mathrm{k}$ and $\mathrm{h}$ are Boltzmann and Plank constants, respectively. The kinetic and thermodynamic parameters are compiled in Tables 3-8.

\section{Conclusion remarks}

(i) Non-isothermal decomposition of the complexes under study resembles the reaction

$$
\begin{aligned}
& \mathrm{A}_{(\mathrm{s})} \rightarrow \mathrm{B}_{(\mathrm{s})}+\mathrm{C}_{(\mathrm{g})} \\
& \text { which can be studied } \\
& \text { kinetically. }
\end{aligned}
$$

(ii) The calculated activation energies of the complexes are relatively low indicating their relative law stability. The activation energy values of the copper complexes are lower than those of the corresponding nickel complexes which can be attributed to the autocatalytic effect of copper on the thermal decomposition of the copper complexes. Catalytic activity of many compounds containing $\mathrm{Cu}$ (II) was reported in the literature $^{14 \& 15}$.

(iii) In most cases the kinetic parameters observed in the Horowitz-Metzger equation are higher than that of the values from Coats-Redfern equation. This is due to the inherent error involved in the approximation method employed in the derivation of HorowitzMetzger equation ${ }^{12}$.

(iv) The value of $\Delta \mathrm{G}^{*}$ increases significantly for the subsequent decomposition stages of a given complex. This is due to increasing the values of $\mathrm{T} \Delta \mathrm{S}^{*}$ from one stage to another which overrides the values of $\Delta \mathrm{H}^{*}$. The $\Delta \mathrm{G}^{*}$ increase reflects also that the rate of removal of the subsequent ligand will be lower than that of the precedent ligand $^{16 \& 17}$. This may be attributed to the structural rigidity of the remaining complex after the expulsion of one and more ligands, as compared with the precedent complex, which requires more energy, $\mathrm{T} \Delta \mathrm{S}^{*}, \quad$ for its arrangement before undergoing any compositional change.

(v) The negative values of $\Delta \mathrm{S}^{*}$ for all the complexes means that the activation complex is more ordered than the reactants and 
Table 3: Kinetic parameters for the thermal decomposition of $[\mathrm{Cu}(\mathrm{OHAE})(2-\mathrm{Atz})]$ and $[\mathrm{Cu}(\mathrm{OHAE})(\mathrm{Btz})]$.

\begin{tabular}{|c|c|c|c|c|c|c|c|c|c|}
\hline \multirow{2}{*}{ Compound } & \multirow{2}{*}{ Step } & \multicolumn{4}{|c|}{ Coats-Redfern equation } & \multicolumn{4}{|c|}{ Horowitz-Metzger equation } \\
\hline & & $\mathrm{n}$ & $r$ & $\mathrm{E}$ & $\mathrm{Z}$ & $\mathrm{n}$ & $r$ & $\mathrm{E}$ & $\mathrm{Z}$ \\
\hline \multirow{12}{*}{$\begin{array}{l}\text { [Cu(OHAE)- } \\
(2-A t z)]\end{array}$} & \multirow[t]{6}{*}{$3^{\text {rd }}$} & 0.0 & 0.998 & 39.9 & $7.9 \times 10^{4}$ & 0.0 & 0.996 & 49.6 & $5.4 \times 10^{3}$ \\
\hline & & 0.3 & $\underline{0.999}$ & 46.9 & $2.3 \times 10^{4}$ & 0.3 & $\underline{0.999}$ & 57.6 & $7.3 \times 10^{3}$ \\
\hline & & 0.5 & 0.997 & 49.8 & $9.9 \times 10^{3}$ & 0.5 & 0.997 & 59.5 & $8.7 \times 10^{3}$ \\
\hline & & 0.6 & 0.996 & 53.7 & $5.3 \times 10^{3}$ & 0.6 & 0.995 & 62.6 & $2.2 \times 10^{4}$ \\
\hline & & 1.0 & 0.995 & 61.6 & $1.5 \times 10^{3}$ & 1.0 & 0.981 & 72.4 & $7.6 \times 10^{4}$ \\
\hline & & 0.0 & 0.981 & 91.5 & $3.9 \times 10^{6}$ & 2.0 & 0.980 & 103.3 & $8.6 \times 10^{6}$ \\
\hline & \multirow[t]{6}{*}{$5^{\text {th }}$} & 0.0 & 0.979 & 158.6 & $6.3 \times 10^{5}$ & 0.0 & 0.991 & 170.9 & $5.4 \times 10^{4}$ \\
\hline & & 0.3 & 0.986 & 183.5 & $1.8 \times 10^{7}$ & 0.3 & 0.993 & 192.1 & $3.8 \times 10^{6}$ \\
\hline & & 0.5 & 0.989 & 190.6 & $3.8 \times 10^{7}$ & 0.5 & 0.997 & 201.2 & $7.1 \times 10^{8}$ \\
\hline & & 0.6 & 0.992 & 209.5 & $4.2 \times 10^{8}$ & 0.6 & 0.998 & 219.3 & $2.9 \times 10^{9}$ \\
\hline & & 1.0 & $\underline{0.996}$ & 228.7 & $4.5 \times 10^{10}$ & 1.0 & $\underline{0.999}$ & 237.2 & $3.6 \times 10^{11}$ \\
\hline & & 2.0 & 0.995 & 342.6 & $6.8 \times 10^{13}$ & 2.0 & 0.986 & 350.1 & $5.4 \times 10^{14}$ \\
\hline \multirow{12}{*}{$\begin{array}{l}{[\mathrm{Cu}(\mathrm{OHAE})-} \\
(\mathrm{Btz})]\end{array}$} & \multirow[t]{6}{*}{$1^{\mathrm{st}}$} & 0.0 & 0.971 & 26.6 & $5.6 \times 10^{3}$ & 0.0 & 0.973 & 20.4 & $5.6 \times 10^{3}$ \\
\hline & & 0.3 & 0.986 & 31.9 & $1.1 \times 10^{4}$ & 0.3 & 0.985 & 25.4 & $8.2 \times 10^{3}$ \\
\hline & & 0.5 & 0.993 & 35.5 & $9.5 \times 10^{4}$ & 0.5 & 0.989 & 29.3 & $1.6 \times 10^{4}$ \\
\hline & & 0.6 & 0.996 & 38.1 & $3.9 \times 10^{5}$ & 0.6 & 0.993 & 34.1 & $3.1 \times 10^{4}$ \\
\hline & & 1.0 & $\underline{0.999}$ & 48.1 & $4.8 \times 10^{6}$ & 1.0 & $\underline{0.998}$ & 45.2 & $5.6 \times 10^{5}$ \\
\hline & & 2.0 & 0.991 & 84.9 & $2.1 \times 10^{8}$ & 2.0 & 0.997 & 78.3 & $4.6 \times 10^{7}$ \\
\hline & \multirow[t]{6}{*}{$2^{\text {nd }}$} & 0.0 & 0.996 & 73.1 & $1.8 \times 10^{4}$ & 0.0 & 0.991 & 85.9 & $2.3 \times 10^{3}$ \\
\hline & & 0.3 & 0.997 & 83.2 & $1.6 \times 10^{5}$ & 0.3 & 0.994 & 90.5 & $1.2 \times 10^{4}$ \\
\hline & & 0.5 & 0.998 & 88.3 & $2.6 \times 10^{5}$ & 0.5 & 0.996 & 93.6 & $3.7 \times 10^{4}$ \\
\hline & & 0.6 & $\underline{0.999}$ & 93.9 & $1.8 \times 10^{6}$ & 0.6 & $\underline{0.997}$ & 98.7 & $6.1 \times 10^{6}$ \\
\hline & & 1.0 & 0.993 & 104.7 & $1.3 \times 10^{7}$ & 1.0 & 0.989 & 110.7 & $5.6 \times 10^{7}$ \\
\hline & & 2.0 & 0.991 & 146.7 & $4.6 \times 10^{10}$ & 2.0 & 0.988 & 150.9 & $4.8 \times 10^{10}$ \\
\hline
\end{tabular}

$\mathrm{E}$ in $\mathrm{kJmol}^{-1}, \mathrm{Z}$ in s ${ }^{-1}$. 
Table 4: Kinetic parameters for the thermal decomposition of $[\mathrm{Cu}(\mathrm{OHAE})(3-\mathrm{Msbtz})]$ and $[\mathrm{Cu}(\mathrm{OHAE})(\mathrm{Tbdz})] \cdot \mathrm{H}_{2} \mathrm{O}$.

\begin{tabular}{|c|c|c|c|c|c|c|c|c|c|}
\hline \multirow{2}{*}{ Compound } & \multirow{2}{*}{ Step } & \multicolumn{4}{|c|}{ Coats-Redfern equation } & \multicolumn{4}{|c|}{ Horowitz-Metzger equation } \\
\hline & & $\mathrm{n}$ & $r$ & $\mathrm{E}$ & $\mathrm{Z}$ & $\mathrm{n}$ & $r$ & $\mathrm{E}$ & $\mathrm{Z}$ \\
\hline \multirow{12}{*}{$\begin{array}{l}{[\mathrm{Cu}(\mathrm{OHAE})-} \\
\text { (3-Msbtz)] }\end{array}$} & \multirow[t]{6}{*}{$2^{\text {nd }}$} & 0.0 & 0.972 & 27.9 & $5.5 \times 10^{4}$ & 0.0 & 0.970 & 23.2 & $4.6 \times 10^{3}$ \\
\hline & & 0.3 & 0.986 & 32.8 & $8.1 \times 10^{4}$ & 0.3 & 0.975 & 27.3 & $7.3 \times 10^{3}$ \\
\hline & & 0.5 & 0.991 & 37.8 & $3.5 \times 10^{3}$ & 0.5 & 0.980 & 30.7 & $2.6 \times 10^{4}$ \\
\hline & & 0.6 & 0.992 & 41.7 & $4.9 \times 10^{4}$ & 0.6 & 0.990 & 35.7 & $4.1 \times 10^{4}$ \\
\hline & & 1.0 & $\underline{0.997}$ & 50.6 & $9.1 \times 10^{4}$ & 1.0 & $\underline{0.998}$ & 37.8 & $5.6 \times 10^{5}$ \\
\hline & & 0.0 & 0.992 & 90.7 & $2.1 \times 10^{9}$ & 2.0 & 0.991 & 81.9 & $5.7 \times 10^{8}$ \\
\hline & \multirow[t]{6}{*}{$3^{\text {rd }}$} & 0.0 & 0.991 & 76.3 & $2.7 \times 10^{4}$ & 0.0 & 0.990 & 82.2 & $3.9 \times 10^{3}$ \\
\hline & & 0.3 & 0.993 & 87.4 & $3.6 \times 10^{5}$ & 0.3 & 0.992 & 87.3 & $1.2 \times 10^{4}$ \\
\hline & & 0.5 & 0.994 & 91.4 & $4.6 \times 10^{5}$ & 0.5 & 0.993 & 90.6 & $5.7 \times 10^{4}$ \\
\hline & & 0.6 & $\underline{0.995}$ & 95.5 & $3.2 \times 10^{6}$ & 0.6 & 0.996 & 94.3 & $7.2 \times 10^{5}$ \\
\hline & & 1.0 & 0.994 & 110.6 & $2.7 \times 10^{7}$ & 1.0 & $\underline{0.991}$ & 105.7 & $7.1 \times 10^{6}$ \\
\hline & & 2.0 & 0.990 & 150.7 & $5.7 \times 10^{11}$ & 2.0 & 0.989 & 145.1 & $8.7 \times 10^{10}$ \\
\hline \multirow{12}{*}{$\begin{array}{l}{[\mathrm{Cu}(\mathrm{OHAE})-} \\
(\mathrm{Tbdz})] \cdot \mathrm{H}_{2} \mathrm{O}\end{array}$} & \multirow[t]{6}{*}{$2^{\text {nd }}$} & 0.0 & 0.971 & 27.7 & $5.5 \times 10^{4}$ & 0.0 & 0.977 & 19.7 & $6.1 \times 10^{3}$ \\
\hline & & 0.3 & 0.979 & 32.6 & $5.8 \times 10^{4}$ & 0.3 & 0.986 & 22.9 & $8.1 \times 10^{3}$ \\
\hline & & 0.5 & 0.992 & 37.5 & $7.3 \times 10^{4}$ & 0.5 & 0.988 & 27.6 & $1.7 \times 10^{4}$ \\
\hline & & 0.6 & 0.995 & 39.5 & $8.1 \times 10^{4}$ & 0.6 & 0.989 & 37.6 & $3.7 \times 10^{4}$ \\
\hline & & 1.0 & $\underline{0.998}$ & 50.9 & $9.1 \times 10^{4}$ & 1.0 & $\underline{0.997}$ & 42.7 & $6.1 \times 10^{5}$ \\
\hline & & 2.0 & 0.991 & 87.7 & $1.3 \times 10^{8}$ & 2.0 & 0.990 & 79.8 & $4.8 \times 10^{7}$ \\
\hline & \multirow[t]{6}{*}{$3^{\text {rd }}$} & 0.0 & $\underline{0.999}$ & 70.5 & $2.8 \times 10^{4}$ & 0.0 & $\underline{0.999}$ & 80.8 & $3.3 \times 10^{3}$ \\
\hline & & 0.3 & 0.990 & 81.7 & $2.9 \times 10^{5}$ & 0.3 & 0.991 & 91.9 & $2.3 \times 10^{4}$ \\
\hline & & 0.5 & 0.992 & 89.6 & $3.1 \times 10^{5}$ & 0.5 & 0.992 & 95.7 & $4.8 \times 10^{4}$ \\
\hline & & 0.6 & 0.991 & 95.5 & $2.8 \times 10^{6}$ & 0.6 & 0.998 & 98.5 & $7.1 \times 10^{6}$ \\
\hline & & 1.0 & 0.993 & 110.7 & $4.7 \times 10^{7}$ & 1.0 & 0.989 & 110.6 & $7.1 \times 10^{7}$ \\
\hline & & 2.0 & 0.987 & 150.6 & $5.6 \times 10^{12}$ & 2.0 & 0.988 & 160.7 & $5.9 \times 10^{11}$ \\
\hline
\end{tabular}

$\mathrm{E}$ in $\mathrm{kJmol}^{-1}, \mathrm{Z}$ in s${ }^{-1}$. 
Table 5: Kinetic parameters for the thermal decomposition of $[\mathrm{Ni}(\mathrm{SOP})(2-$ Atz] and [Ni(SOP)(Btz)].

\begin{tabular}{|c|c|c|c|c|c|c|c|c|c|}
\hline \multirow{2}{*}{ Compound } & \multirow{2}{*}{ Step } & \multicolumn{4}{|c|}{ Coats-Redfern equation } & \multicolumn{4}{|c|}{ Horowitz-Metzger equation } \\
\hline & & $\mathrm{n}$ & $r$ & E & Z & $\mathrm{n}$ & $r$ & E & Z \\
\hline \multirow{12}{*}{$\begin{array}{l}\text { [Ni(SOP)- } \\
\text { (2-Atz)] }\end{array}$} & \multirow[t]{6}{*}{$3^{\text {rd }}$} & 0.0 & 0.983 & 105.1 & $2.6 \times 10^{5}$ & 0.0 & 0.991 & 113.0 & $2.4 \times 10^{6}$ \\
\hline & & 0.3 & 0.989 & 126.7 & $1.6 \times 10^{6}$ & 0.3 & 0.992 & 135.7 & $1.4 \times 10^{6}$ \\
\hline & & 0.5 & 0.991 & 135.2 & $4.7 \times 10^{6}$ & 0.5 & 0.994 & 145.6 & $3.7 \times 10^{7}$ \\
\hline & & 0.6 & 0.993 & 151.1 & $6.1 \times 10^{7}$ & 0.6 & 0.995 & 160.3 & $7.8 \times 10^{9}$ \\
\hline & & 1.0 & $\underline{0.999}$ & 182.5 & $2.3 \times 10^{10}$ & 1.0 & $\underline{0.997}$ & 189.4 & $8.1 \times 10^{9}$ \\
\hline & & 0.0 & 0.990 & 285.6 & $5.7 \times 10^{21}$ & 2.0 & 0.990 & 300.2 & $9.9 \times 10^{20}$ \\
\hline & \multirow[t]{6}{*}{$4^{\text {th }}$} & 0.0 & 0.980 & 91.0 & $2.3 \times 10^{3}$ & 0.0 & 0.980 & 102.1 & $4.0 \times 10^{2}$ \\
\hline & & 0.3 & 0.981 & 107.3 & $2.1 \times 10^{4}$ & 0.3 & 0.983 & 118.5 & $1.7 \times 10^{3}$ \\
\hline & & 0.5 & 0.985 & 116.2 & $9.2 \times 10^{4}$ & 0.5 & 0.985 & 127.6 & $2.5 \times 10^{3}$ \\
\hline & & 0.6 & 0.988 & 125.7 & $5.0 \times 10^{5}$ & 0.6 & 0.988 & 136.5 & $6.2 \times 10^{4}$ \\
\hline & & 1.0 & 0.993 & 148.5 & $9.4 \times 10^{6}$ & 1.0 & 0.994 & 157.7 & $2.9 \times 10^{5}$ \\
\hline & & 2.0 & $\underline{0.998}$ & 150.2 & $4.6 \times 10^{8}$ & 2.0 & 0.999 & 161.1 & $2.1 \times 10^{7}$ \\
\hline \multirow{18}{*}{$\begin{array}{l}{[\mathrm{Ni}(\mathrm{SOP})-} \\
(\mathrm{Btz})]\end{array}$} & \multirow[t]{6}{*}{$1^{\mathrm{st}}$} & 0.0 & 0.998 & 31.6 & $6.2 \times 10^{4}$ & 0.0 & 0.997 & 40.9 & $8.3 \times 10^{3}$ \\
\hline & & 0.3 & 0.997 & 34.3 & $2.7 \times 10^{4}$ & 0.3 & 0.998 & 43.8 & $9.1 \times 10^{3}$ \\
\hline & & 0.5 & 0.996 & 36.4 & $1.4 \times 10^{4}$ & 0.5 & 0.996 & 48.9 & $5.7 \times 10^{4}$ \\
\hline & & 0.6 & 0.994 & 38.5 & $9.7 \times 10^{3}$ & 0.6 & 0.995 & 50.7 & $7.1 \times 10^{4}$ \\
\hline & & 1.0 & $\underline{0.999}$ & 43.2 & $6.8 \times 10^{3}$ & 1.0 & $\underline{0.999}$ & 55.6 & $8.1 \times 10^{4}$ \\
\hline & & 2.0 & 0.993 & 57.2 & $2.9 \times 10^{4}$ & 2.0 & 0.990 & 63.3 & $3.1 \times 10^{5}$ \\
\hline & \multirow[t]{6}{*}{$2^{\text {nd }}$} & 0.0 & 0.966 & 75.9 & $4.8 \times 10^{3}$ & 0.0 & 0.974 & 91.0 & $8.9 \times 10^{3}$ \\
\hline & & 0.3 & 0.972 & 84.8 & $2.7 \times 10^{3}$ & 0.3 & 0.978 & 101.9 & $7.3 \times 10^{3}$ \\
\hline & & 0.5 & 0.974 & 89.4 & $7.1 \times 10^{3}$ & 0.5 & 0.980 & 106.6 & $1.5 \times 10^{4}$ \\
\hline & & 0.6 & 0.977 & 94.3 & $1.9 \times 10^{4}$ & 0.6 & 0.981 & 111.7 & $3.7 \times 10^{4}$ \\
\hline & & 1.0 & 0.981 & 105.1 & $5.3 \times 10^{4}$ & 1.0 & 0.984 & 115.8 & $5.3 \times 10^{4}$ \\
\hline & & 2.0 & $\underline{0.990}$ & 140.0 & $8.9 \times 10^{5}$ & 2.0 & 0.991 & 153.7 & $2.1 \times 10^{5}$ \\
\hline & \multirow[t]{6}{*}{$3^{\text {rd }}$} & 0.0 & 0.996 & 95.6 & $3.8 \times 10^{3}$ & 0.0 & 0.997 & 78.9 & $5.1 \times 10^{2}$ \\
\hline & & 0.3 & 0.991 & 115.7 & $1.1 \times 10^{5}$ & 0.3 & 0.989 & 106.7 & $5.2 \times 10^{4}$ \\
\hline & & 0.5 & 0.990 & 128.2 & $8.1 \times 10^{5}$ & 0.5 & 0.975 & 118.7 & $6.1 \times 10^{4}$ \\
\hline & & 0.6 & 0.989 & 140.3 & $5.6 \times 10^{6}$ & 0.6 & 0.979 & 131.5 & $7.1 \times 10^{5}$ \\
\hline & & 1.0 & 0.986 & 168.0 & $2.6 \times 10^{8}$ & 1.0 & 0.978 & 157.8 & $7.3 \times 10^{7}$ \\
\hline & & 2.0 & 0.985 & 226.1 & $6.8 \times 10^{15}$ & 2.0 & 0.976 & 255.9 & $8.1 \times 10^{14}$ \\
\hline
\end{tabular}

$\mathrm{E}$ in $\mathrm{kJmol}^{-1}, \mathrm{Z}$ in s${ }^{-1}$. 
Table 6: Kinetic parameters for the thermal decomposition of $[\mathrm{Ni}(\mathrm{SOP})(2-$ Mbtz] and [Ni(SOP)(Morph)].

\begin{tabular}{|c|c|c|c|c|c|c|c|c|c|}
\hline \multirow{2}{*}{ Compound } & \multirow{2}{*}{ Step } & \multicolumn{4}{|c|}{ Coats-Redfern equation } & \multicolumn{4}{|c|}{ Horowitz-Metzger equation } \\
\hline & & $\mathrm{n}$ & $r$ & $\mathrm{E}$ & $\mathrm{Z}$ & $\mathrm{n}$ & $r$ & $\mathrm{E}$ & $\mathrm{Z}$ \\
\hline \multirow{12}{*}{$\begin{array}{l}{[\mathrm{Ni}(\mathrm{SOP})-} \\
(2-\mathrm{Mbtz})]\end{array}$} & \multirow[t]{6}{*}{$2^{\text {nd }}$} & 0.0 & 0.985 & 73.7 & $4.8 \times 10^{3}$ & 0.0 & 0.971 & 91.5 & $5.6 \times 10^{3}$ \\
\hline & & 0.3 & 0.987 & 82.3 & $2.7 \times 10^{3}$ & 0.3 & 0.978 & 100.6 & $8.2 \times 10^{4}$ \\
\hline & & 0.5 & 0.988 & 89.2 & $6.9 \times 10^{3}$ & 0.5 & 0.980 & 105.2 & $2.6 \times 10^{4}$ \\
\hline & & 0.6 & 0.990 & 90.4 & $1.7 \times 10^{4}$ & 0.6 & 0.981 & 113.3 & $3.2 \times 10^{4}$ \\
\hline & & 1.0 & 0.992 & 103.2 & $6.1 \times 10^{4}$ & 1.0 & 0.985 & 116.4 & $5.6 \times 10^{4}$ \\
\hline & & 0.0 & $\underline{0.997}$ & 140.9 & $9.1 \times 10^{5}$ & 2.0 & $\underline{0.991}$ & 150.1 & $4.6 \times 10^{5}$ \\
\hline & \multirow[t]{6}{*}{$3^{\text {rd }}$} & 0.0 & $\underline{\underline{0.996}}$ & 96.9 & $3.8 \times 10^{3}$ & 0.0 & 0.997 & 80.9 & $6.1 \times 10^{2}$ \\
\hline & & 0.3 & $\overline{0.991}$ & 116.5 & $9.1 \times 10^{4}$ & 0.3 & $\overline{0.989}$ & 110.7 & $5.6 \times 10^{3}$ \\
\hline & & 0.5 & 0.986 & 130.8 & $8.1 \times 10^{5}$ & 0.5 & 0.985 & 119.5 & $7.2 \times 10^{4}$ \\
\hline & & 0.6 & 0.97 & 142.5 & $5.6 \times 10^{6}$ & 0.6 & 0.981 & 135.6 & $8.5 \times 10^{5}$ \\
\hline & & 1.0 & 0.977 & 170.3 & $3.1 \times 10^{7}$ & 1.0 & 0.984 & 160.8 & $8.4 \times 10^{7}$ \\
\hline & & 2.0 & 0.978 & 270.4 & $3.1 \times 10^{14}$ & 2.0 & 0.987 & 260.4 & $8.9 \times 10^{13}$ \\
\hline \multirow{18}{*}{$\begin{array}{l}\text { [Ni(SOP)- } \\
\text { (Morph)] }\end{array}$} & \multirow[t]{6}{*}{$1^{\text {st }}$} & 0.0 & 0.979 & 16.9 & $7.1 \times 10^{2}$ & 0.0 & 0.980 & 25.9 & $2.1 \times 10^{3}$ \\
\hline & & 0.3 & 0.986 & 18.9 & $7.3 \times 10^{3}$ & 0.3 & 0.982 & 27.7 & $9.2 \times 10^{3}$ \\
\hline & & 0.5 & 0.990 & 19.5 & $1.5 \times 10^{4}$ & 0.5 & 0.985 & 28.9 & $1.6 \times 10^{4}$ \\
\hline & & 0.6 & 0.993 & 20.6 & $1.1 \times 10^{5}$ & 0.6 & 0.987 & 30.7 & $8.1 \times 10^{4}$ \\
\hline & & 1.0 & 0.997 & 23.8 & $9.1 \times 10^{5}$ & 1.0 & 0.992 & 33.6 & $7.6 \times 10^{5}$ \\
\hline & & 2.0 & $\underline{0.998}$ & 32.1 & $5.2 \times 10^{6}$ & 2.0 & $\underline{0.999}$ & 43.7 & $6.6 \times 10^{6}$ \\
\hline & \multirow[t]{6}{*}{$2^{\text {nd }}$} & 0.0 & 0.982 & 79.3 & $2.8 \times 10^{3}$ & 0.0 & 0.981 & 95.7 & $6.3 \times 10^{2}$ \\
\hline & & 0.3 & 0.987 & 89.3 & $7.6 \times 10^{3}$ & 0.3 & 0.985 & 97.7 & $6.2 \times 10^{3}$ \\
\hline & & 0.5 & 0.989 & 95.7 & $2.6 \times 10^{4}$ & 0.5 & 0.987 & 112.3 & $3.7 \times 10^{4}$ \\
\hline & & 0.6 & 0.992 & 101.2 & $6.8 \times 10^{4}$ & 0.6 & 0.988 & 118.5 & $4.1 \times 10^{4}$ \\
\hline & & 1.0 & $\underline{0.994}$ & 113.7 & $3.3 \times 10^{5}$ & 1.0 & $\underline{0.991}$ & 122.7 & $1.6 \times 10^{5}$ \\
\hline & & 2.0 & 0.990 & 158.9 & $3.6 \times 10^{9}$ & 2.0 & $\overline{0.989}$ & 167.9 & $1.8 \times 10^{8}$ \\
\hline & \multirow[t]{6}{*}{$3^{\text {rd }}$} & 0.0 & 0.978 & 84.7 & $2.3 \times 10^{3}$ & 0.0 & 0.980 & 96.7 & $6.6 \times 10^{2}$ \\
\hline & & 0.3 & 0.982 & 96.5 & $5.4 \times 10^{3}$ & 0.3 & 0.985 & 107.8 & $7.7 \times 10^{3}$ \\
\hline & & 0.5 & 0.986 & 103.3 & $2.3 \times 10^{4}$ & 0.5 & 0.989 & 114.9 & $3.2 \times 10^{3}$ \\
\hline & & 0.6 & 0.989 & 109.4 & $3.1 \times 10^{4}$ & 0.6 & 0.991 & 120.1 & $5.6 \times 10^{4}$ \\
\hline & & 1.0 & $\underline{0.996}$ & 126.7 & $5.7 \times 10^{5}$ & 1.0 & $\underline{0.995}$ & 136.3 & $7.1 \times 10^{4}$ \\
\hline & & 2.0 & 0.995 & 182.1 & $6.8 \times 10^{9}$ & 2.0 & $\overline{0.993}$ & 192.4 & $7.1 \times 10^{9}$ \\
\hline
\end{tabular}

$\mathrm{E}$ in $\mathrm{kJmol}^{-1}, \mathrm{Z}$ in s${ }^{-1}$. 
Table 7: Kinetic parameters for the thermal decomposition of $[\mathrm{Cu}(\mathrm{SOP})(\mathrm{Btz})]$ and $\left[\mathrm{Cu}(\mathrm{SOT})_{2}(\mathrm{Morph})_{2}\right]$.

\begin{tabular}{|c|c|c|c|c|c|c|c|c|c|}
\hline \multirow{2}{*}{ Compound } & \multirow{2}{*}{ Step } & \multicolumn{4}{|c|}{ Coats-Redfern equation } & \multicolumn{4}{|c|}{ Horowitz-Metzger equation } \\
\hline & & $\mathrm{n}$ & $r$ & $\mathrm{E}$ & $\mathrm{Z}$ & $\mathrm{n}$ & $r$ & E & $\mathrm{Z}$ \\
\hline \multirow{12}{*}{$\begin{array}{l}{[\mathrm{Cu}(\mathrm{SOP})-} \\
(\mathrm{Btz})]\end{array}$} & $1^{\text {st }}$ & 0.0 & 0.983 & 22.9 & $2.6 \times 10^{3}$ & 0.0 & 0.986 & 30.7 & $5.3 \times 10^{3}$ \\
\hline & & 0.3 & 0.988 & 25.7 & $1.1 \times 10^{4}$ & 0.3 & 0.988 & 32.5 & $8.2 \times 10^{4}$ \\
\hline & & 0.5 & 0.990 & 26.6 & $9.5 \times 10^{4}$ & 0.5 & 0.990 & 35.6 & $5.6 \times 10^{5}$ \\
\hline & & 0.6 & 0.991 & 27.5 & $6.9 \times 10^{4}$ & 0.6 & 0.992 & 37.8 & $3.1 \times 10^{5}$ \\
\hline & & 1.0 & $\underline{0.995}$ & 41.0 & $3.9 \times 10^{4}$ & 1.0 & $\underline{0.999}$ & 39.7 & $8.7 \times 10^{5}$ \\
\hline & & 0.0 & 0.991 & 75.8 & $2.1 \times 10^{5}$ & 2.0 & 0.998 & 49.8 & $4.6 \times 10^{6}$ \\
\hline & $2^{\text {nd }}$ & 0.0 & 0.975 & 25.9 & $1.8 \times 10^{3}$ & 0.0 & 0.980 & 20.9 & $4.3 \times 10^{3}$ \\
\hline & & 0.3 & 0.978 & 29.5 & $9.6 \times 10^{3}$ & 0.3 & 0.983 & 27.5 & $2.2 \times 10^{3}$ \\
\hline & & 0.5 & 0.981 & 35.6 & $5.6 \times 10^{4}$ & 0.5 & 0.985 & 33.7 & $6.7 \times 10^{3}$ \\
\hline & & 0.6 & 0.985 & 39.8 & $8.8 \times 10^{4}$ & 0.6 & 0.987 & 36.5 & $6.3 \times 10^{4}$ \\
\hline & & 1.0 & $\underline{0.990}$ & 43.7 & $1.1 \times 10^{3}$ & 1.0 & $\underline{0.995}$ & 40.7 & $9.7 \times 10^{4}$ \\
\hline & & 2.0 & 0.983 & 65.5 & $3.6 \times 10^{5}$ & 2.0 & 0.991 & 61.5 & $4.5 \times 10^{6}$ \\
\hline \multirow{6}{*}{$\begin{array}{l}{\left[\mathrm{Cu}(\mathrm{SOT})_{2}\right.} \\
- \\
\left.(\mathrm{Morph})_{2}\right]\end{array}$} & $3^{\text {rd }}$ & 0.0 & 0.989 & 94.7 & $3.3 \times 10^{4}$ & 0.0 & 0.990 & 105.6 & $4.7 \times 10^{3}$ \\
\hline & & 0.3 & 0.990 & 106.1 & $5.4 \times 10^{5}$ & 0.3 & 0.992 & 118.7 & $6.6 \times 10^{4}$ \\
\hline & & 0.5 & 0.993 & 114.6 & $2.3 \times 10^{6}$ & 0.5 & 0.993 & 126.3 & $3.2 \times 10^{5}$ \\
\hline & & 0.6 & 0.996 & 121.6 & $9.1 \times 10^{6}$ & 0.6 & 0.995 & 133.5 & $6.6 \times 10^{6}$ \\
\hline & & 1.0 & $\underline{0.998}$ & 139.7 & $1.4 \times 10^{8}$ & 1.0 & $\underline{0.997}$ & 144.3 & $5.1 \times 10^{7}$ \\
\hline & & 2.0 & 0.997 & 203.8 & $6.8 \times 10^{10}$ & 2.0 & 0.991 & 218.2 & $7.2 \times 10^{9}$ \\
\hline
\end{tabular}

$\mathrm{E}$ in $\mathrm{kJmol}^{-1}, \mathrm{Z}$ in s${ }^{-1}$ 
Table 8: Thermodynamic parameters for decomposition of the complexes.

\begin{tabular}{|c|c|c|c|c|c|c|c|}
\hline \multirow[b]{2}{*}{ Compound } & \multirow[b]{2}{*}{ Step } & \multicolumn{3}{|c|}{ Coats-Redfern equation } & \multicolumn{3}{|c|}{ Horowitz-Metzger equation } \\
\hline & & $\begin{array}{c}\Delta \mathrm{S}^{*} \\
\mathrm{JK}^{-1} \mathrm{~mol}^{-1} \\
\end{array}$ & $\begin{array}{c}\Delta \mathrm{H}^{*} \\
\mathrm{kJmol}^{-1} \\
\end{array}$ & $\begin{array}{c}\Delta \mathrm{G}^{*} \\
\mathrm{kJmol}^{-1}\end{array}$ & $\begin{array}{c}\Delta \mathrm{S}^{*} \\
\mathrm{JK}^{-1} \mathrm{~mol}^{-1} \\
\end{array}$ & $\begin{array}{c}\Delta \mathrm{H}^{*} \\
\mathrm{kJmol}^{-1}\end{array}$ & $\begin{array}{c}\Delta \mathrm{G}^{*} \\
\mathrm{kJmol}^{-1}\end{array}$ \\
\hline \multirow{2}{*}{$\begin{array}{l}{[\mathrm{Cu}(\mathrm{OHAE})-} \\
(2-\mathrm{Atz})]\end{array}$} & $3^{\mathrm{rd}}$ & -166.5 & 42.3 & 135.5 & -176.0 & 53.0 & 151.5 \\
\hline & $5^{\text {th }}$ & -50.7 & 220.6 & 270.4 & -33.4 & 229.1 & 261.8 \\
\hline \multirow{3}{*}{$\begin{array}{l}{[\mathrm{Cu}(\mathrm{OHAE})-} \\
(\mathrm{Btz})]\end{array}$} & $1^{\text {st }}$ & -119.3 & 44.8 & 92.6 & -137.3 & 41.9 & 96.9 \\
\hline & $2^{\text {nd }}$ & -131.1 & 88.0 & 171.5 & -121.3 & 93.4 & 170.7 \\
\hline & $4^{\text {th }}$ & -125.1 & 184.0 & 302.5 & -140.4 & 173.1 & 306.2 \\
\hline \multirow{2}{*}{$\begin{array}{l}{[\mathrm{Cu}(\mathrm{OHAE})-} \\
(3-\mathrm{Msbtz})]\end{array}$} & $2^{\text {nd }}$ & -152.6 & 47.2 & 110.2 & -137.4 & 34.4 & 91.1 \\
\hline & $3^{\mathrm{rd}}$ & -125.8 & 90.8 & 163.4 & -138.2 & 89.5 & 169.4 \\
\hline \multirow{2}{*}{$\begin{array}{l}{[\mathrm{Cu}(\mathrm{OHAE})-} \\
(\mathrm{Tbdz})] \cdot \mathrm{H}_{2} \mathrm{O}\end{array}$} & $2^{\text {nd }}$ & -153.9 & 46.9 & 121.2 & -138.1 & 38.7 & 105.4 \\
\hline & $3^{\mathrm{rd}}$ & -165.3 & 65.6 & 163.6 & -183.3 & 75.9 & 185.8 \\
\hline \multirow{2}{*}{$\begin{array}{l}{[\mathrm{Ni}(\mathrm{SOP})-} \\
(2-\mathrm{Atz})]\end{array}$} & $3^{\mathrm{rd}}$ & -53.6 & 176.7 & 214.4 & -62.3 & 183.6 & 227.4 \\
\hline & $4^{\text {th }}$ & -87.2 & 143.6 & 213.6 & -112.6 & 154.1 & 244.9 \\
\hline \multirow{3}{*}{$\begin{array}{l}{[\mathrm{Ni}(\mathrm{SOP})-} \\
(\mathrm{Btz})]\end{array}$} & $1^{\mathrm{st}}$ & -174.8 & 39.5 & 118.3 & -155.4 & 51.9 & 122.0 \\
\hline & $2^{\text {nd }}$ & -138.0 & 134.2 & 230.9 & -149.7 & 147.9 & 252.8 \\
\hline & $3^{\mathrm{rd}}$ & -184.4 & 89.0 & 236.7 & -201.1 & 72.3 & 233.4 \\
\hline \multirow{2}{*}{$\begin{array}{l}{[\mathrm{Ni}(\mathrm{SOP})-} \\
(2-\mathrm{Mbtz})]\end{array}$} & $2^{\text {nd }}$ & -137.8 & 135.1 & 231.3 & -141.0 & 144.3 & 242.7 \\
\hline & $3^{\mathrm{rd}}$ & -184.5 & 90.3 & 237.5 & -199.7 & 74.3 & 233.5 \\
\hline \multirow{3}{*}{$\begin{array}{l}{[\mathrm{Ni}(\mathrm{SOP})-} \\
(\mathrm{Morph})]\end{array}$} & $1^{\text {st }}$ & -120.2 & 28.1 & 86.2 & -99.8 & 39.7 & 88.0 \\
\hline & $2^{\text {nd }}$ & -145.5 & 107.9 & 209.9 & -170.9 & 116.9 & 236.7 \\
\hline & $3^{\mathrm{rd}}$ & -151.6 & 120.0 & 241.9 & -160.2 & 129.6 & 258.4 \\
\hline \multirow{2}{*}{$\begin{array}{l}{[\mathrm{Cu}(\mathrm{SOP})-} \\
(\mathrm{Btz})] \\
\end{array}$} & $1^{\text {st }}$ & -159.3 & 37.7 & 101.6 & -133.6 & 30.4 & 90.0 \\
\hline & $2^{\text {nd }}$ & -192.5 & 38.4 & 161.0 & -160.1 & 27.6 & 129.6 \\
\hline $\begin{array}{l}{\left[\mathrm{Cu}(\mathrm{SOT})_{2^{-}}\right.} \\
\left.(\mathrm{Morph})_{2}\right]\end{array}$ & $2^{\text {nd }}$ & -95.5 & 134.3 & 197.1 & -103.8 & 138.9 & 207.2 \\
\hline
\end{tabular}


that the reactions are slow. The more ordered nature may be due to polarization of bonds in the activation state, which might happen through charge transfer electronic transitions ${ }^{9}$.

\section{REFERENCES}

1- C. P. Raptopoulou, A. N. Papadopoulou, D. A. Malamatari, E. Loannidis, G. Molsidis, A. Terzis and D. P. Kessissoglou, Inorg. Chim. Acta, 272, 283 (1998).

2- T. Snamt and S. Umezari, Bull. Chem. Soc. Jpn., 29, 975 (1956).

3- N. Dharmaj, P. Viswanathamurthi and $\mathrm{K}$. Natarajan, Transition Met. Chem., 26, 105 (2001).

4- S. C. Mojumdar, M. Melnik and E. Jona, Thermochim. Acta, 352, 157 (2000) and references therein.

5- L. S. Goodman and A. Gilman, "The Pharmacological Basis of Therapeutics", $\quad 5^{\text {th }}$ Ed. Macmillan, New York (1975).

6- R. Lackhan and B. Ternai, Adv. Heterocy. Chem., 17, 99 (1974)
7- A. A. M. Aly, M. S. El-Meligy, A. S. A. Zidan and M. ElShabasy, Synth. React. Inorg. Met.-Org. Chem., 17, 257 (1987).

8- A. A. M. Aly, M. S. El-Meligy, A. S. Zidan and M. El-Shabasy, An. Quim., 86, 19 (1990).

9- A. H. Osman, A. A. M. Aly, M. Abd El-Mottaleb and G. A. H. Gouda, Bull. Korean Chem. Soc., 25, 45 (2004).

10- A. A. M. Aly, A. H. Osman, M. Abd El-Mottaleb and G. A. H. Gouda, Bull. Pharm. Sci., Assiut University, 29, 137 (2006).

11- A. W. Coats and J. P. Redfern, Nature, 20, 68 (1964).

12- H. Horowitz and G. Metzger, Anal. Chem., 35, 1464 (1963).

13- S. Glasston, "Textbook of Physical Chemistry", $2^{\text {nd }}$ Ed., Macmillan, 1974, p. 1103.

14- A. M. El-Awad, J. Therm. Anal. Cal., 61, 197 (2000).

15- A. Imura, Y. Inoue and I. Yasumori, Bull. Chem. Soc. Jpn., 56, 2203 (1983).

16- P. B. Maravalli and T. R. Goudar, Thermochim. Acta, 325, 35 (1999).

17- K. K. M. Yusuff and R. Sreekala, Thermochim. Acta, 159, 357 (1990). 